\title{
Sport jako možnost inkluze osob s mentálním postižením
}

\section{Sport as a Possibility of Inclusion of People with Intellectual Impairment}

\author{
Lucie Francová, KTVS UHK, Hradec Králové
}

\begin{abstract}
Abstrakt:
Nabídka sportovních a pohybových aktivit se stále se rozšiřuje. Přicházejí nové, moderní sporty a obdobně tomu je i u sportouních a pohybouých možností pro osoby s mentálním postižením.

Př́spěvek je přehledovou studií aktuální nabídky sportu pro osoby s mentálním postižením. Vzhledem $k$ charakteristice tohoto postižení má tato nabídka význam hlavně pro rodiče či pečující osoby, ale v době inkluzivního vzdělávání je také třeba informovanosti pedagogických pracouníkũ. Cílem teto studie je osvěta, která sumarizuje aktuální stav. Součástí je představení organizací, které mají aktuálně zastoupení v České republice, s vazbou na organizace mezinárodní a jejich konkrétní nabídka sportů, do které se mohou sportovci s mentálním postižením zapojit.

V návaznosti na nabídku jsou představeny způsoby realizace pohybovǵch aktivit. Do popředí zájmu pečujících osob se stále více dostává spolupráce se sportovními oddíly a trenéry intaktní populace. Příspěvek je doplněn o konkrétní př́iklady a zkušenosti rodičů zapojených do tréninkủ intaktní populace.
\end{abstract}

\section{Klíčová slova}

sport, pohybové aktivity, trénink, osoby s mentálním postižením, organizace

\section{Abstract:}

The offer of sports and physical activities is constantly expanding. New, modern sports are coming and the same trend is in sports and exercise opportunities for people with intellectual impairment.

The paper is a overview study of the current offer of sports for people with intellectual impairment. This offer is important mainly for parents or carers, but in the time of inclusive education, it is necessary to inform teachers, as well. For this reason, this study is a kind of enlightenment that summarizes the current situation. It will include a presentation of organizations that are currently represented in the Czech Republic, with links to international organizations and their specific range of sports that athletes with intellectual impairment can engage.

In connection with the offer, the ways of realization of physical activities are described. Cooperation with sports teams and coaches of the intact population is increasingly comes to the forefront of interest. The paper is supplemented by specific examples and experience of parents involved in the training of the intact population.

\section{Keywords}

sport, physical activity, training, people with intellectual impairment, organization.

\section{Úvod}

Sport, dostatek pohybu a zdravý životní styl jsou velmi aktuální témata a zasahují nejen do oblasti intaktní populace, ale mají své významné místo u jedinců s handicapem. V České republice se po roce 1989 začaly rozšiřovat sportovní nabídky a stále se na základě vývojových trendů rozšǐ̌ují. 
V České republice nabízí sportovní a pohybové možnosti pro osoby s mentálním postižením dvě organizace. Jednou z organizací je Ceské hnutí speciálních olympiád (ČHSO), které je na mezinárodní úrovni zaštítěno Mezinárodním hnutím Speciálních olympiád (SOI). Druhou organizací je Český svaz mentálně postižených sportovců (ČSMPS), na mezinárodníúrovni zastřešený organizací Virtus (World Intellectual Impairment Sport). Název Virtus je používán od roku 2019 a je ho možno překládat jako sport pro osoby s omezením či postižením intelektu. V České republice je stále používán pojem mentální postižení, kdy změny v terminologii v souladu s mezinárodní organizací jsou zvažovány. Partnerskou organizací ČSMPS, která se podílí na zajištění sportu pro osoby s mentálním postižením na národní úrovni, je Český paralympijský výbor (ČPV), na mezinárodní úrovni Mezinárodní paralympijský výbor (IPC - International Paralympic Committeee). Druhou partnerskou organizací je Sportovní unie pro osoby s Down syndrom (SU-DS, Sport Union for athletes with Down Syndrome).

Vzhledem k šíri představených možností pro jeden typ postižení je patrné, že pro zájemce z řad odborné veřejnosti, rodinných příslušníků, pečujících osob či pedagogů může být přínosné zpracování přehledu aktuálně nabízených možností. Příspěvek má za cíl analyzovat dostupné zdroje, zpracovat ucelený a aktualizovaný přehled pohybových a sportovních možností.

\section{Současný stav poznání}

Sport osob s mentálním postižením prošel za posledních 20 let výrazným vývojem a výzkumem aktuálně vedeným Jan Burns z Canterbury Christ Church University a Debbie van Biesen, působící na Katolické univerzitě v Lovani. Výzkum je veden ve spolupráci s mezinárodní organizací Virtus. Burns, J. (2012) uvádí, že sport osob s mentálním postižením není dostatečně podporován a záleží na úsilí a podpoře rodin a jejich příznivců, aby každý sportovec mohl soutěžit dle své úrovně. Na základě výzkumů podpořených Virtus vznikají nové kategorie a rozšíření možností sportu. Vznikají a rozšiřují se i samostatné organizace, které se snaží respektovat šíři postižení. Jednou z takto rychle rozšiřujících organizací je SU-DS (Sport Union for athletes with Down Syndrome). Cílem organizace je podpora pohybových aktivit na soutěžní a srovnatelné úrovni. Snahou je šíření sportovních možností do celého světa a smělou vizí je vytvoření vlastní třídy v rámci paralympijských her (SU-DS, 2021). V České republice je možnost začlenění do SUDS zajištěna v Českém svazu mentálně postižených sportovců (ČSMPS). Český svaz mentálně postižených sportovců (ČSMPS) dodržuje v provozovaných sportech jasná stanovená pravidla a vize mezinárodní organizace Virtus, která podporuje klasický pyramidový sportovní systém, at' se jedná o světové hry tzv. Global Games nebo Paralympijské hry. Lantz, E. \& Marcellini, A. (2017). Kudláček, M. \& Ješina, 0. (2013) uvádí, že sportovci s mentálním postižením se paralympiád účastní jen ve vybraných sportech (atletice, plavání a stolním tenisu) a účast vychází z klasifikace sportovců a splnění daných kritérií či limitů. Širší nabídku sportovních možností poskytuje ČSMPS (mimo paralympijskou větev). Další organizací s velkou nabídkou, ale odlišným přístupem je České hnutí Speciálních olympiád(ČHSO). Podle Kudláčka a Ješiny (2013) je sportovní filosofie ČHSO založena na principu relativity vzhledem k aktuálnímu výkonu. Válková (2012) popisuje dva možné směry sportovních možností pro osoby s mentálním postižením, reprezentované právě dvěma zmíněnými organizacemi ČSMPS a ČHSO. V posledních letech došlo k rozšíření o nové organizace a kategorie.

Jak rozšiřující se nabídka sportovních možností pro osoby s mentálním postižením souvisí s inkluzí? Soutěže, organizované zmíněnými organizacemi jsou samostatnými a cílenými akcemi pro jedince s mentálním postižením. Tilinger (2009) uvádí, že sport nabízí jedincům s mentálním postižením stejné hodnoty, potěšení a uspokojení jako osobám bez handicapu. Sport může dávat nové stimuly, pocit úspěchu, vlastní ceny, výkonu a sounáležitosti a může tím ovlivnit nejen sportovce samotné, ale celé rodiny. Ovlivnění pocitů v souvislosti s pohybovými aktivitami a sportem potvrzují na základě svých výzkumů i Shapiro a Ulrich (2001). Lahtinen, Rintala a Malin (2007) shrnují, že zapojení do pohybových aktivit vede ke zlepšení, zviditelnění, uznání a tím vyšší úrovni společenského postavení.

Účast na soutěžích je vrcholem dlouhodobé snahy a píle, které vychází ze systematické přípravy. Jednou z možností této přípravy jsou společné tréninky či společné soutěže na oddílové nebo regionální úrovni. Pojem společné tréninky, soutěžení obecně společné sportování možno považovat za součást společného vzdělávání, ke kterému se velmi pozitivně vyjadřuje Špotáková (2021), známá profesionální sportovkyně. Špotáková popisuje, že „společné vzdělávání je jednoznačně přínosem pro všechny strany. 
Všichni se od sebe učí navzájem, a čím více mají možnost poznat pestřejší svět, tím více budou v budoucnosti bez předsudkư“. (Špotáková, 2021). Společné vzdělávání může přinášet spoustu úskalí, ale ve sportovním prostředí se otevírají možnosti, které mohou být vhodnou variantou rozvoje osobnosti. Tento moderní trend i v oblasti sportu je v souladu s Kudláčkem, Ješinou (2013), kteří rozdělují integraci do třech rovin (organizační, individuální/tréninkovou a v rámci soutěžní činnosti). Autoři popisují společné soutěže, které probíhají dle regulí a pravidel sportovních svazů, dále uvádějí, že „bez větších problémů může docházet k integraci sportovců se sluchovým postižením. U sportovců se zrakovým a tělesným postižením záleží na charakteristice sportu“ (Kudláček, Ješina, 2021, s. 107). Autoři nezmiňují zapojení osob s mentálním postižením. Tento příspěvek prezentuje zkušenosti rodičů se zapojením svých svěřenců s mentálním postižením do společných tréninků v rámci přípravy na specializované soutěže. Winnick (2000) uvádí, že dětí s mentálním postižením v porovnání s vrstevníky bez postižení mají nižší hodnoty při posouzení motorických schopností či pohybových dovedností, ale zároveň potvrzuje, že se děti s lehkým mentálním postižením mohou zapojit do společného soutěžení se sportovci bez handicapu.

\section{Metoda}

Pro příspěvek byla využita analýza dat a případové studie, zvolené metody byly dotazování a rozhovory. Respondenti byli prvně osloveni telefonicky s vysvětlením záměru a s účastí souhlasili. Byly připraveny otázky, které byly rozeslány respondentům. Do studie byli zařazeni tři respondenti, rodiče, kteří participují na přípravě svých svěřenců s mentálním postižením, kteří se účastní pořádaných soutěží. Po zodpovězení otázek písemně, navázal druhý telefonický rozhovor, který doplnil připravené otázky. Vš̌ichni zúčastnění využívají možnosti společných tréninků a jsou zařazeni do jedné ze specializovaných soutěží pro osoby s mentálním postižením, v rámci ČSMPS. Odpovědi byly přepsány, zpracovány, vzájemně porovnány a analyzovány.

\section{Participující}

1. Rodina, kde sportovkyně je 4 roky v reprezentaci, 10 let se účastní sportovního, společného tréninku. Účastnice soutěží, které pořádá Virtus a IPC (International Paralympic committee) ve stolním tenisu.

2. Rodina, kde je sportovkyně 2 roky v reprezentaci ČSMPS, 15 let byla členka ČHSO, 30 let je ve sportovním tréninku. Účastnice soutěží SU-DS, Virtus ve stolním tenisu (a dříve soutěží ISO - International Special Olympic).

3. Rodina, kde sportovec je 20 let v reprezentaci, absolvoval 25 let sportovního tréninku. Účastník soutěží Virtus v tenisu.

\section{Výsledky}

Tato kapitola představuje jednotlivé sportovní možnosti pro osoby s mentálním postižením a u každé kategorie ČSMPS jsou představeny zkušenosti participujících rodičů s přípravou ve společném tréninku a zhodnocen je přínos využité sportovní nabídky z pohledu rodičů.

\section{Sportouní možnosti, nabídka a soutěže zaštítěné čSMPS Cúl ČMSPS}

Hlavním cílem organizace je „... umožnit sportování lidem s mentálním postižením v co nejširším rozsahu a nabídce, aby si každý zájemce mohl vybrat „svůj“ sport a hlavně - zažít úspěch a radost z pohybu“ (ČSMPS, 2021).

1. Sportovní možnosti, nabídka a soutěže pod mezinárodní organizací Virtus (dříve Inas, Inas-FID). Tematicky výstižná je vize Virtus „An inclusive world for people with an intellectual impairment" (Virtus, 2021).

\section{Sportovní nabídka}

Atletika (součástí je přespolní běh) · Basketbal · Cyklistika · Fotbal · Jezdectví · Judo · Kriket · Lyžování (alpské/běžecké) · Plavání · Stolní tenis · Tenis · Veslování

V České republice je možné se věnovat kurzivou označeným sportům.

Na národní úrovni se provozují další sporty, které nemají mezinárodní záštitu:

Florbal · Nohejbal · Přehazovaná · Turistika. Nově je v ČR zařazen bowling. 
Virtus spolupracuje s mezinárodními federacemi pro podporu dalších sportů:

Golf · Jachting $\cdot$ Karate $\cdot$ Para hokej $\cdot$ Taekwondo.

\section{Cílové skupiny}

Do jednotlivých soutěží jsou sportovci zařazeni dle kategorií II1-3, zkratka II vychází s anglického názvu intellectual impairment (oslabení intelektu). Charakteristika kategorii je následující:

- II1 - Sportovci s oslabením kognitivních funkcí, s IQ pod 75.

- II2 - Sportovci s oslabením kognitivních funkcí, s IQ pod 75 a s dalším významným oslabením. Do kategorie jsou aktuálně zařazení sportovci s diagnózou Down syndrom.

- II3 - Sportovci s autismem či jinou poruchu autistického spektra s IQ nad 75.

\section{Soutěže}

Soutěže jsou pořádány od regionálních a národních soutěží až po Mistrovství Evropy, Mistrovství světa ve dvouletém střídavém cyklu a nejvyšší soutěží jsou světové hry Global Games pořádané ve čtyřletém cyklu.

\section{Zkušenosti rodičů}

Rodiče popisují, že v rámci přípravy využívají jak tréninků organizovaných pro sportovce s mentálním postižením, tak tréninků v oddílech intaktní populace. Vytvořené možnosti hodnotí: „Náš syn je vždy přijímán bezproblémově, at už v rámci tréninků, soustředění ČSMPS či tréninků s intaktní populací, které velmi využíváme."

Sportovní možnosti shrnují rodiče tím, že přináší „... radost ze sportu, náplň života, úspěchy i porážky, družstvo kamarádůo, uznání... Kamarády z členů družstva možná na celý život.“

\section{Sportovní možnosti, nabídka a soutěže pod mezinárodní organizací IPC}

Tato nabídka se týká soutěží pořádaných současně pro osoby s tělesným, zrakovým postižením a jedna ze tříd je určena sportovcům s mentálním postižením, v České republice organizované Českým paralympijským výborem (ČPV).

\section{Cíl ČpV}

ČPV „....podporuje rozvoj sportu zdravotně postižených, a tím také přispívá k jejich společenské integraci, a zaštitíuje přípravu handicapovaných sportovců na vrcholné světové soutěže."(ČPV, 2021).

\section{Sportovní nabídka}

Sporty pro osoby s mentálním postižením pod záštitou ČPV:

Atletika · Plavání · Stolní tenis.

\section{Cílové skupiny}

Do soutěží organizovaných IPC/ČPV je zařazena pouze jedna supina, shrnující všechny sportovce s mentálním postižením, splňující klasifikační a nominační pravidla. Každý sport má své individuální označení:

- Atletika - tř́́da T/F 20,

- Plavání - tř́ida SB14,

- Stolní tenis - třída 11.

\section{Soutěže}

Soutěže se pořádají od regionálních po národní soutěže. V mezinárodním měřítku jsou pořádány série závodů každého sportu, Mistrovství Evropy, Mistrovství světa, kde průběžně dochází k plnění nominačních pravidel a k případné kvalifikaci na soutěž nejvyšší, kterou je Paralympiáda.

\section{Zkušenosti rodičů}

Rodiče se maximálně věnují rozvoji své dcery po všech stránkách. Výrazná je podpora právě ve sportovní oblasti. Situaci umocňuje i sportovní zaměření rodičů, kteří jsou součástí přípravného týmu ve více sportech. Sportovkyně se účastní jak individuálních tréninků pod profesionálním vedením, tak tréninků v oddíle běžné populace. Obdobně tomu je v soutěžích, kdy se účastní akcí třídy 11, tak soutěží pořádaných pro 
sportovce bez handicapu. Přínos možností sportovat spatřují rodiče v získání nových kamarádů a pocitu že: „...i s handicapem může být úspěšná sportovkyně“.

\section{Sportovní možnosti, nabídka a soutěže pod mezinárodní organizací SU-DS Cúl SU-DS \\ Celosvětová propagace sportu pro osoby s Down syndrom (SUDS, 2021).}

\section{Sportovní nabídka}

Atletika · 3x3 Basketbal · Futsal · Gymnastika · Judo · Lyžování · Plavání \& Synchronizované plavání · Stolní tenis $\cdot$ Tenis.

\section{Cílová skupiny}

Do jednotlivých soutěží jsou sportovci zařazeni dle diagnózy a při registraci se dále uvádí konkrétní členění:

- Down syndrom Trisomy 21,

- Down syndrom Mosaic.

\section{Soutěže}

Soutěže na regionálních či národních úrovních probíhají většinou ve sloučených kategoriích s ostatními sportovci s mentálním postižením. V mezinárodním měřítku se pořádají Mistrovství Evropy, Mistrovství světa a nejvyšší soutěží jsou světové hry Tri-Games.

\section{Zkušenosti rodičů}

Shodně s ostatními respondenty se i tato rodina velmi výrazně podílí na rozvoji a zdokonalování dovedností zvoleného sportu. Své dceři rodiče umožňují každodenní tréninky, at' individuální nebo opět v oddílech intaktní populace, v jejichž týmu nastupuje i do společných soutěží. Společné tréninky hodnotí rodiče jako přínosné a z pohledu ostatních sportovců v oddíle bez předsudků. Vyjádření, co sport přinesl, je „... pocit platnosti, důkaz schopností, pocit štěstí, radost a uspokojení."

\section{4. Športovní možnosti, nabídka a soutěže zaštítěné čHSO Cíl ČHSO}

„Cílem Speciálních Olympiád je umožnit co největšímu počtu lidí s mentálním postižením pravidelně sportovat a účastnit se sportovních soutěží bez ohledu na absolutní výkonnost.“(ČHSO, 2021).

\section{Sportovní nabídka}

Atletika · Badminton · Bocce · Bowling · Cyklistika · Florbal · Fotbal · Gymnastika · Krasobruslení · Lyžování (alpské/běžecké) · Plavání · Pozemní hokej · Přehazovaná · Stolní tenis · Snowbording · Tanec · Volejbal.

\section{Cílová skupina}

„Speciální olympijský program je otevřen všem lidem s mentálním postižením, kteří dovršili 8 let a jejichž IQ není vyšší než 80. Dolní hranice IQ není určena, to znamená, že do sportovní činnosti mohou a mají být zapojováni i jedinci s těžkým stupněm mentálního postižení.“(ČHSO, 2021).

\section{Rozdělení do skupin}

„Sportovci jsou při sportovních soutěžích rozděleni zásadně do skupin podle své výkonnosti a každému z nich se nakonec dostane ocenění a uznání. Vyhrát tak mohou i sportovci s těžkým stupněm mentálního postižení."(ČHSO, 2021).

\section{Soutěže}

Soutěže jsou pořádány jako národní turnaje daných sportů, v pravidelných intervalech se pořádají Národní letní a zimní hry. Reprezentanti ČHSO mohou reprezentovat na Světových hrách.

\section{Diskuse}


V porovnání s Válkovou (2012) je doplněna nabídka možností pro osoby s mentálním postižením tak, že reflektuje aktuální stav. Nabídka je doplněna o zkušenosti rodičů s přínosem sportu pro jejich děti. Popisována je velká škála převážně pozitivních pocitů a prožitků, které přináší zapojení do sportu a velmi výrazně ovlivňují rozvoj osobnosti samotného sportovce, tak rodičů. Tato zjištění jsou ve shodě s tvrzeními Shapiro a Ulricha (2001) a Lahtinen, Rintala a Malin (2007), kteří popisují ovlivnění pocitů a osobností všech zúčastněných. Jsou popisovány nejen individuální pocity radosti, uspokojení, seberealizace a hrdosti, ale i velmi důležité sociální vazby v rámci začlenění do skupiny, pocity sounáležitosti, které popisuje Tilinger (2009). Z rozboru odpovědí rodičů možno zhodnotit velkou snahu, ochotu a nasazení rodinných příslušníků, kteří se věnují svým dětem, což potvrzuje i Burns (2012), která vidí aktivizaci děti s mentálním postižením právě v maximálním úsilí a podpoře rodin.

Rodiče se shodují nejen v přínosu pohybu obecně, ale i v zařazování svých dětí do tréninků a programů intaktní populace, do běžných sportovních oddílů a soutěží. Shodné názory se objevují při popisu bezproblémového přijetí, ochotě a zájmu vzájemně spolupracovat. Kudláček, Ješina (2013) uvádějí prvky společného sportování u sportovců se sluchovým postižením a u sportovců se zrakovým či tělesným postižením dle charakteristiky sportu. Ze získaných odpovědí rodičů vyplývá, že tato praxe velmi dobře funguje i u osob s mentálním postižním a nese s sebou jasné benefity vzájemného obohacení, které popisuje i Śpotáková (2021). V tomto pohledu bych zdůraznila známé tvrzení, že „cesta je cíl“, kdy inkluzivní možností je právě zapojení osob s handicapem do společných tréninků, které jsou cestou k cíli, kterým může být některá z mezinárodních soutěží. Samotné představené soutěže nejsou inkluzivní, ale přinášejí nenahraditelné pocity uspokojení, radosti, sebevědomí, seberealizace, důležité pro každého jedince. Popisované společné trénování, společné regionální soutěže, celková společná systematická příprava přináší sportovcům navzájem dobré př́klady, správné pohybové vzory, inspirace, podněty, respekt, ale i obdiv k odhodlání a je popisovanou možností inkluze. Proti tomu při děleném sportování jednotlivých skupiny se zmíněné benefity v takovém rozsahu nevyskytují nebo ani vyskytovat nemohou. Dle mého názoru vzniká ucelená možnost vzájemného obohacení společným tréninkem a návazně prostor vyniknout ve srovnatelné skupině, což má na osobnost jedince jednoznačný a rodiči potvrzený př́nos.

\section{Závěr}

Cílem této studie bylo analýza aktuální sportovní nabídky pro osoby s mentálním postižením. Součástí bylo zjištění názoru a přínosu sportu pro děti s mentálním postižením z pohledu participujících rodičů. Ze zjištěných názorů plyne jednoznačný přínos sportu pro jedince s mentálním postižením i jejich rodiče. Velmi výrazně vyznívá důležitost rodiny a její podpory, kdy nyní v době inkluze přechází role hledání zájmů a smysluplného trávení volného času na rodinu.

Z celého textu plyne, že se týká malé skupiny sportovců, kteří dokázali s pomocí a podporou rodiny rozvinout míru svých dovedností a schopnosti na velmi vysokou úroveň a stali se nejlepšími ve svých kategoriích. Celý text měl být příkladem, ukázkou, inspirací, co je možné dosáhnout, nejen př́klady z praxe, ale i ukázkou široké škály od zdravotních (s tím související výkonnostních) kategorií, variability sportů a organizací. Osoby s postižením, či jejich rodinnípříslušníci mohou prostřednictvím představené nabídky a zkušeností najít směr či vhodnou cestu pro řešení své situace.

V rámci shrnutí nutno vyjádřit obdiv sportovcům se zdravotním postižením samotným, ale také obrovský respekt rodičům, kteří našli tu správnou cestu pro podporu svých dětí a smysl života.

\section{Literatura}

Burns, J. (2012). What does the Olympics mean to you? The Psychologist, 25(7), 508-509.

České hnutí speciálních olympiád. (2021). Retrieved from https://www.specialolympics.cz/0-nas

Český paralympijský výbor. (2021). Retrieved from https://paralympic.cz/cpv/

Český svaz mentálně postižených sportovců. (2021). Retrieved from https://www.csmps.cz/0-svazu/

Kudláček, M., \& Ješina, 0. (2013). Integrovaná tělesná výchova, rekreace a sport. Olomouc: Palackého Univerzita, Česká Republika.

Lantz, E., \& Marcellini, A. (2017). Sports games for people with intellectual disabilities. Institutional analysis of an unusual international configuration. Sport in Society, 21(4):1-14. https://doi. org/10.4324/9780429197437-6

Tilinger, P. (2009). Sport osob s mentálním postižením. Prague: Karlova Univerzita, Česká Republika. 
Shapiro, R. D., \& Ulrich, A. D. (2001). Social comparisons of children with and without learning disabilities when evaluating physical competence. Adapted physical activity quarterly, 18, 273-288. https:// doi.org/10.1123/apaq.18.3.273

Sport Union for athletes with Down Syndrome. (2021). Retrieved from https://www.su-ds.org/about-us/

Špotáková, B. (2021). Společné vzdělávání je přirozená věc. Retrieved from https://www.msmt.cz/ministerstvo/novinar/nejdulezitejsi-roli-hraje-informovanost

Válková, H. (2012). Sport osob s mentálním postižením. In Vybrané kapitoly ze sportu osob se zdravotním postižením.(101-107). Olomouc: Palackého Univerzita, Česká Republika.

Virtus (2021). Retrieved from https://www.virtus.sport/about-virtus

Winnick, J. P. (2000). Adapted physical education and sport. $3^{\text {rd ded. Human Kinetics. }}$

\title{
Informace o autorech
}

\author{
Mgr. et Mgr. Lucie Francová, Ph.D. \\ KTVS PdF Univerzity Hradec Králové \\ Mistopředseda pro zahraničí ČSMPS \\ Telefon: +420 602153695 \\ Email: lucie.francova@uhk.cz
}

